\title{
Kemampuan Pemecahan Masalah Matematis melalui Pembelajaran Penemuan Terbimbing
}

\author{
Irni Latifa Irsal \\ Institut Agama Islam Negeri (IAIN) Curup \\ irni.latifa@iaincurup.ac.id
}

\begin{tabular}{l}
\hline \hline Article Info \\
\hline Article history: \\
Received April $13^{\text {th }}, 2020$ \\
Revised May $10^{\text {th }}, 2020$ \\
Accepted May $22^{\text {th }}, 2020$ \\
\hline
\end{tabular}

Keywords:

Problem Solving Skill;

Discovery Learning

\begin{abstract}
The gap between facts and the importance of problem solving skill to be developed, into cornerstone of this research. Research of improving students' problem solving skill through guided discovery learning is the aim of this research. Qualitative descriptive be the method in this research. Pre-test and post-test was completed by 38 students. Pre-test and post-test result were analyzed descriptively. To get in-depth data about students' problem solving ability, interviews were conducted with 20 students. Results of interviews, observations, and research journals were analyzed qualitatively. There is a difference in the improvement of problem solving skill, seen from the increase on total value and the increase on each indicator of problem solving skill. In total value, the increase have is in the low category. Also the increase of $1^{\text {st }}$ indicator and $3^{\text {rd }}$ indicator is in thw low category. But, indicator $2^{\text {nd }}$ and $4^{\text {th }}$ is in the medium category.
\end{abstract}

Kata Kunci:

Kemampuan pemecahan masalah;

Penemuan Terbimbing

\section{Abstrak}

Kesenjangan antara fakta dan pentingnya kemampuan pemecahan masalah untuk dikembangkan menjadi landasan dilakukan penelitian ini. Kajian tentang peningkatan kemampuan pemecahan masalah siswa melalui pembelajaran penemuan terbimbing, menjadi tujuan dalam penelitian ini. Penelitian mengadopsi deskriptif kualitatif menjadi metode dalam penelitian. Sebanyak 38 siswa diminta untuk mengerjakan soal pretest dan post-test. Selanjutnya data hasil pre-test dan post-test dianalisis secara deskriptif, 20 orang siswa diwawancari untuk mendapatkan data yang lebih mendalam mengenai kemampuan pemecahan masalah siswa. Hasil wawancara, observasi, dan catatan peneliti 
dianalisis secara kualitatif. Ada perbedaan peningkatan kemampuan pemecahan masalah, bila dilihat dari rerata peningkatan nilai total dan rerata peningkatan kemampuan pemecahan masalah pada masing-masing indikator. Peningkatan kemampuan pemecahan masalah dilihat dari nilai total, tergolong pada kategori rendah. Peningkatan kemampuan pemecahan masalah pada indikator 1 dan indikator 3 tergolong pada kategori rendah. Sedangkan, indikator 2 dan indikator 4 tergolong pada kategori sedang.

\section{PENDAHULUAN}

Kemampuan pemecahan merupakan salah satu kemampuan yang dinilai sangat penting untuk dikembangkan dalam pembelajaran matematika (NCTM, 2000; Killpatrick \& Swafford, 2002; Devlin, 2007; Kurikulum 2013). Masalah, tidak hanya muncul pada pembelajaran saja, namun muncul pada setiap aktivitas kehidupan manusia. Masalah bisa berupa masalah rutin, non-rutin, tertutup, dan terbuka (Sternberg dan Ben-Zeev, 1996; Yee, 2002a; Yee, 2002b). Untuk menyelesaikan masalah, diperlukan peguasaan kemampuan pemecahan masalah dengan baik. Sulit untuk menyelesaikan suatu masalah, bila tidak memiliki dan menguasai kemampuan pemecahan masalah (Ruseffendi, 2006). Bila dikaitkan dengan kesuksesan, individu akan dikatakan sukses ketika mampu untuk menyelesaikan masalah dengan baik dan tepat. Dengan kata lain, kunci kesuksesan dalam kehidupan salah satunya adalah memiliki dan menguasai kemampuan pemecahan masalah (Khan, 2013).

Mengembangkan kemampuan pemecahan masalah, sama halnya dengan mengembangkan kemampuan analitis, kritis, logis, fleksibel, dan kreatif. Hal yang serupa diungkapkan oleh Suryadi \& Herman (2004), ketika individu menguasai kemampuan pemecahan masalah dengan baik, maka individu tersebut menguasai kemampuan matematis lainnya dengan baik pula. Menurut Prabawanto (2013), ada empat kriteria individu memiliki dan menguasai kemampuan pemecahan masalah dengan baik, yakni ketika individu tersebut mampu untuk: (1) menyelesaikan masalah matematis tertutup dengan konteks di dalam matematika; (2) 
menyelesaikan masalah matematis tertutup dengan konteks di luar matematika; (3) menyelesaikan masalah terbuka dengan konteks di dalam matematika; (4) menyelesaikan masalah terbuka dengan konteks di luar matematika.

Pentingnya kemampuan pemecahan masalah untuk dikuasai, tidak sejalan dengan beberapa fakta yang ditunjukkan. Beberapa penelitian yang telah dilakukan menunjukkan bahwa lemahnya kemampuan pemecahan masalah siswa. Lemahnya kemampuan pemecahan masalah juga diungkapkan oleh Herawati (2010) dalam penelitiannya. Herawati (2010) mengungkapkan bahwa kemampuan pemecahan masalah siswa berada dalam kategori yang lemah, disebabkan lemahnya kemampuan pemahaman siswa. Fakta yang sama juga tergambar pada penelitian oleh Uhti (2011), Husna (2013), dan Mulyadi (2015). Uhti (2011) dan Husna (2013) mengungkapkan pada penelitiannya bahwa kemampuan pemecahan masalah siswa SMP masih tergolong lemah. Hal tersebut dapat terjadi dikarenakan siswa masih terpaku dan terbiasa pada permasalahan rutin yang memiliki tingkat kesulitan yang rendah dan proses yang sederhana. Penelitian oleh Mulyadi (2015) mengungkapkan bahwa lemahnya kemampuan pemecahan masalah disebabkan oleh kesalahan siswa dalam memahami masalah, serta memahami konsep.

Lemahnya kemampuan pemecahan masalah yang tersaji pada beberapa fakta yang ada, diduga disebabkan oleh pembelajaran yang selama ini masih berfokus pada pengembangan kemampuan matematika secara kuantitas bukan secara kualitas. Sesuai dengan hasil observasi yang dilakukan, sekolah masih menunjukkan penggunaan pembelajaran ceramah kepada siswa. Pemberian tugas dilakukan sebagai selingan selama proses ceramah berlangsung. Interaksi siswa dan guru selama proses pembelajaran berlangsung dinilai minim, siswa lebih banyak mendengar dan mencatat.

Perlu pembelajaran berbeda yang dapat meningkatkan aktifitas belajar siswa, sehingga akan ada peningkatan pada kemampuan pemecahan masalah siswa. Pembelajaran yang dianggap mampu memberikan pembelajaran aktif kepada siswa salah satunya adalah pembelajaran model penemuan terbimbing. Gulo (2008) menyatakan 
bahwa pembelajaran dengan model penemuan terbimbing merupakan rangkaian kegiatan yang melibatkan seluruh kemampuan siswa untuk mencari dan menyelidiki secara sistematis, kritis, logis, serta analitis. Menurut Rahmawati (2014) dan Rosdianwinata (2015) model penemuan terbimbing sangat cocok untuk meningkatkan kemampuan pemecahan masalah. Terdapat enam tahapan proses pembelajaran menggunakan model penemuan terbimbing menurut Syah (2006), yakni: (1) stimulation; (2) problem statement; (3) data collection; (4) data processing; (5) verification; (6) generalisation.

Masing-masing tahapan pada pembelajaran penemuan terbimbing memiliki peran pada peningkatan kemampuan pemecahan masalah siswa. Tahap stimulation dan problem statement, merupakan tahap awal untuk membiasakan siswa untuk aktif dan berpikir kritis. Siswa dilatih untuk memahami masalah tanpa mengenal teori yang digunakan untuk menyelesaikan masalah. Siswa dilatih untuk menyelesaikan masalah secara intuisi hanya menggunakan logika saja, tidak menuntut untuk penyelesaian yang benar. Kedua tahapan ini merupakan tahapan awal bagi siswa untuk membangun secara aktif dan mandiri kemampuan pemahaman siswa terhadap teori yang akan digunakan sebagai alat penyelesaian masalah. Ketika siswa membangun pemahaman akan teori dengan caranya sendiri, maka teori tersebut akan lebih lama diingat (Schunk,2012; Jacob, 2003). Pemahaman yang tersusun dengan baik dan benar, nantinya akan membantu dalam menyelesaikan masalah.

Tahap data collection dan processing, merupakan tahap penemuan (Markaban, 2006; Syah ,2006). Kedua tahapan ini melatih siswa dalam hal mengatur strategi penyelesaian masalah. Setelah dihadapkan dengan masalah, siswa dituntut untuk menemukan teori yang diperlukan untuk menyelesaikan masalah secara mandiri dengan bimbingan guru/tutor. Secara aktif ,dengan menggunakan atau tanpa menggunakan pengetahuan terdahulu, siswa menemukan teori yang akan digunakan dalam penyelesaian masalah.

Tahap verification dan generalisation, merupakan tahapan untuk membangun sikap ilmiah siswa. Kedua tahapan ini melatih siswa untuk dapat menilai secara mandiri setiap proses penyelesaian masalah yang 
telah dibuat. Siswa dilatih untuk dapat memperbaiki setiap kesalahan yang ditemukan pada proses penyelesaian masalah. Siswa dilatih untuk mampu mengevaluasi dan mampu mengambil makna dari setiap rangkaian proses penyelesaian masalah (Gulo, 2008; Markaban, 2006; Syah, 2006).

Keterkaitan antara pembelajaran penemuan terbimbing dan upaya peningkatan kemampuan pemecahan masalah, menjadi landasan utama dalam penelitian ini. Penggambaran tentang peningkatan kemampuan pemecahan masalah melalui pembelajaran model penemuan terbimbing penting untuk dilakukan.

\section{METODE PENELITIAN}

Penelitan ini mengadopsi metode penelitian deksriptif kualitatif. Data dalam penelitian dikumpulkan dengan cara pemberian tes, wawancara, serta observasi. Sampel pada penelitian adalah 38 siswa dari salah satu sekolah menengah pertama di Lembang, Bandung. Seluruh siswa diberikan 4 (empat) butir tes kemampuan pemecahan masalah. Tes dilakukan sebelum (pre test) dan sesudah (post test) pembelajaran penemuan terbimbing berlangsung.

Tes berbentuk essai dikembangkan dan digunakan pada pre-test dan post-test. Materi dalam tes yang dikembangkan adalah materi garis dan sudut, kelas 7 semester ganjil. Tes dikembangkan dengan memperhatikan indikator kemampuan pemecahan masalah oleh Prabawanto (2013). Indikator kemampuan pemecahan masalah yang dimaksud yakni: (1) menyelesaikan masalah matematis tertutup dengan konteks di dalam matematika; (2) menyelesaikan masalah matematis tertutup dengan konteks di luar matematika; (3) menyelesaikan masalah matematis terbuka dengan konteks di dalam matematika; (4) menyelesaikan masalah matematis terbuka dengan konteks di luar matematika. Tes divalidasi secara logik oleh dua orang ahli dan secara empiris. Uji validasi secara empiris dilakukan dengan uji coba tes kepada 40 orang siswa, dimana siswa yang menjadi sampel adalah siswa yang telah mempelajari materi garis dan sudut. Hasil uji coba diolah menggunakan bantuas SPSS. 
Jarak antara pre-test dan post-test adalah 2 (dua) bulan lebih, hal ini bertujuan untuk meminimalkan ingatan siswa akan soal pre-test yang diberikan. Sebanyak 20 orang siswa dipilih untuk diwawancarai. Wawancara berfungsi untuk menggambarkan lebih lanjut karakter kemampuan pemecahan masalah siswa. Siswa tersebut dipilih dengan mempertimbangkan jawaban yang diberikan dan kemampuan awal yang dimiliki.

Data dianalisis secara deskriptif dan kualitatif. Analisis data secara deskriptif menggunakan bantuan Microsoft Excel. Analisis data secara kualitatif dilakukan berdasarkan lembar jawaban siswa baik yakni pre-test dan post-test, hasil rekaman wawancara, serta catatan peneliti selama pengumpulan data berlangsung (observasi). Analisis peningkatan kemampuan diulas pada masing-masing indikator kemampuan pemecahan masalah matematis dengan memperhatikan empat langkah penyelesaian pemecahan masalah oleh Polya (1973) yakni memahami masalah, membuat strategi pemecahan masalah, melakukan strategi penyelesaian masalah, dan meninjau kembali hasil penyelesaian.

\section{HASIL PENELITIAN DAN PEMBAHASAN}

Tabel 1 menyajikan hasil dari penelitian yang merupakan gambaran peningkatan kemampuan siswa setelah mendapatkan pembelajaran penemuan terbimbing, ditinjau dari peningkatan pada masing-masing indikator serta peningkatan secara keseluruhan (nilai total). Tiap indikator kemampuan pemecahan masalah diwakili oleh masing-masing soal yang telah dikembangkan. Indikator ke-1 yakni menyelesaikan masalah matematis tertutup dengan konteks di dalam matematika, diwakili oleh soal no.7. Indikator ke-2 yakni menyelesaikan masalah matematis tertutup dengan konteks di luar matematika, diwakili oleh soal no.5. Indikator ke3 yakni menyelesaikan masalah matematis terbuka dengan konteks di dalam matematika, diwakili oleh soal no.4. Indikator ke-4 yakni menyelesaikan masalah matematis terbuka dengan konteks di luar matematika, diwakili oleh soal no.6. 
Tabel 1. Persentase Peningkatan Kemampuan Pemecahan Masalah

\begin{tabular}{cccccc}
\hline & Indikator & Indikator & Indikator & Indikator & Total \\
& $\mathbf{1}$ & $\mathbf{2}$ & $\mathbf{3}$ & $\mathbf{4}$ & \\
\hline $\mathrm{N}$ & 38 & 38 & 38 & 38 & 38 \\
\hline \% peningkatan & 24,76 & 29,87 & 19,39 & 28,79 & 25,71 \\
\hline
\end{tabular}

Berdasarkan persentase total peningkatan kemampuan pemecahan masalah siswa pada Tabel 1, peningkatan terjadi sebesar 25,71\%. Besaran persentase total peningkatan kurang dari $50 \%$, yang bermakna secara keseluruhan peningkatan yang terjadi masuk dalam kategori rendah. Hal ini bersesuaian dengan teori pembagian data, dimana data yang kurang dari 27\% merupakan data pada kelas rendah (Sudijono, 2011; Sugiyono, 2014). Hasil peningkatan yang diperoleh berbeda dengan hasil peningkatan kemampuan pemecahan masalah yang didapatkan oleh penelitian terdahulu. Hasil peningkatan yang diperoleh berbeda dengan hasil peningkatan pada beberapa penelitian yang telah dilakukan. Hasil penelitian oleh Nugroho dan Widodo (2018) menunjukkan peningkatan kemampuan pemecahan masalah matematis siswa sebesar $33,76 \%$. Dimana peningkatan tersebut masuk dalam kategori sedang. Hasil yang sama ditunjukkan oleh Akinbobola \& Afolabi (2010) serta yang menunjukkan bahwa peningkatan kemampuan pemecahan masalah siswa berada pada kategori sedang.

Hasil peningkatan kemampuan pemecahan masalah dapat dipengaruhi oleh intake siswa, kemampuan awal siswa, serta pola belajar siswa. Berdasarkan intake siswa, menurut Setyawan (2012), semakin baik intake siswa maka akan semakin baik pula prestasi belajar yang dihasilkan dan sebaliknya. Berdasarkan hasil observasi awal yang telah dilakukan, intake siswa pada sekolah yang menjadi sampel penelitian masuk dalam kategori rendah. Hampir seluruh siswa yang masuk pada sekolah tersebut adalah siswa yang tidak berhasil masuk pada sekolah unggulan di daerah tersebut.

Rendahnya intake siswa, menggambarkan pula kemampuan awal matematis siswa yang rendah. Rendahnya kemampuan awal matematis ini, menjadi alasan rendahnya peningkatan kemampuan pemecahan masalah matematis secara "total". Kemampuan awal siswa dalam 
menguasai materi prasyarat sangat mempengaruhi keberhasilan penguasaan materi baru. Sejalan dengan pendapat Lestari (2017) serta Herviansyah dan Megawati (2017), yang menyatakan bahwa kemampuan awal siswa akan sangat mempengaruhi hasil belajar siswa, kemampuan awal yang buruk, akan menyebabkan hasil belajar yang buruk. Faktor lainnya, yakni pola belajar "siswa pasif" turut bertanggung jawab pada hasil peningkatan yang rendah bila dilihat dari nilai keseluruhan.

Pola pembelajaran yang membiasakan siswa untuk menerima, bukan mencari, menyebabkan kemampuan berpikir tingkat tinggi siswa sulit untuk berkembang. Di sekolah tempat penelitian berlangsung, menunjukkan pola pembelajaran "siswa pasif" dimana siswa menunggu untuk "disuapi" semua ilmu oleh guru. Siswa tidak dituntut untuk memiliki "kualitas" pemahaman yang baik. Siswa cenderung diajarkan untuk menghapal setiap rumus matematika, beserta contoh penggunaannya, ketimbang diajarkan untuk memahami rumus tersebut. Pola pembelajaran "siswa pasif" ini, hanya mampu mendukung siswa untuk mengembangkan kemampuan berpikir tingkat rendah, bukan berpikir tingkat tinggi (Suryadi,2012).

Pola pembelajaran "siswa pasif" yang selalu digunakan pada pembelajaran sehari-hari di sekolah, menyebabkan siswa membutuhkan waktu yang lama untuk menyesuaikan diri pada pembelajaran baru, khususnya pembelajaran "siswa aktif". Penemuan terbimbing, yang merupakan pembelajaran "siswa aktif", memerlukan waktu yang cukup panjang untuk dapat diterima dan disesuaikan oleh siswa. Berdasarkan hasil pengamatan selama penelitian, siswa mulai terbiasa untuk mandiri, terbiasa untuk berusaha, dan terbiasa untuk berpikir aktif, dimulai pada pertemuan ke-4 dari total 7 pertemuan. Dampak negatif dari pembiasaan ini adalah hilangnya fokus siswa dalam pembelajaran, sehingga kurangnya pemahaman siswa terhadap konten pembelajaran. Dibutuhkan waktu yang lebih lama untuk mengembalikan fokus siswa, sehingga keberhasilan yang didapat akan semakin baik. Suhendra (2008) berpendapat, semakin lama waktu belajar, maka akan semakin baik keberhasilan penyerapan pembelajaran. 
Tabel 1 menunjukkan peningkatan yang berbeda bila dilihat pada peningkatan masing-masing indikator kemampuan pemecahan masalah. Indikator 1 dan indikator 3, memiliki peningkatan sebesar 24,76\% dan $19,39 \%$ dimana nilai peningkatan ini tergolong rendah. Sedangkan untuk indikator 2 dan indikator 4 memiliki nilai peningkatan yang tergolong sedang, dengan besar persentase peningkatan sebesar $29,87 \%$ dan $28,79 \%$. Perbedaan persentase peningkatan pada masing-masing indikator disebabkan oleh konteks yang berbeda. Masalah pada indikator 1 dan indikator 3, mengangkat masalah pada konteks di dalam matematika. Masalah pada indikator 2 dan indikator 4, mengangkat masalah pada konteks di luar matematika yakni konteks kehidupan sehari-hari.

Lebih tingginya peningkatan kemampuan pemecahan masalah pada indikator 2 dan indikator 4 bila dibandingkan dengan indikator 1 dan indikator 3, menunjukkan bahwa siswa lebih cepat menyerap permasalahan yang berkaitan dengan kehidupan keseharian. indikator 1 dan indikator 2 merupakan indikator pengukur kemampuan pemecahan masalah siswa pada masalah tertutup. Indikator 3 dan indikator 4 merupakan indikator pengukur kemampuan pemecahan masalah siswa pada masalah terbuka. Lebih tingginya kemampuan pemecahan masalah dalam menyelesaikan masalah tertutup serta terbuka di luar konteks matematika atau konteks sehari-hari, dibandingkan dengan masalah tertutup serta terbuka di dalam konteks matematika, disebabkan oleh tahap perkembangan mental siswa. Berdasarkan teori perkembangan mental oleh Piaget, siswa SMP pada umur berkisar 11- 13 berada pada tahapan akhir operasi konkret (Ruseffendi, 2006).

Siswa pada tahapan akhir operasional konkret akan lebih mudah untuk menyerap permasalahan dan pembelajaran yang bersifat konkret dibanding bersifat abstrak. Kemampuan siswa untuk membayangkan dan berfikir secara abstrak pada rentang umur 11-13 tahun, memasuki fase awal dalam perkembangannya (Ruseffendi, 2006). Hal yang serupa diungkapkan oleh Aini \& Hidayati (2017) dalam penelitiannya mengenai tahap perkembangan kognitif matematika siswa SMP. Pada penelitian Aini \& Hidayati (2017) menyatakan bahwa siswa pada jenjang kelas 7 SMP, baik laki-laki ataupun perempuan memasuki tahap konkret akhir. 
Makna dari tahap konkret akhir adalah para siswa berada pada tahap konkret menuju formal. Siswa pada tahapan konkret akhir dalam proses awal membagun kemampuan berpikir formal.

Peningkatan pada kemampuan memecahkan masalah terbuka dan tertutup di luar matematika merupakan salah satu dampak positif dari proses pembelajaran penemuan terbimbing. Masalah yang dimunculkan pada tahapan stimulation dan problem statement cenderung mengkaitkan matematika dengan kejadian yang muncul di kehidupan sehari-hari. Hal ini dilakukan dengan mempertimbangkan tahapan perkembangan mental siswa pada umur 11-13 tahun yang masih dalam tahapan akhir operasional konkret. Selain itu, menurut Sauji (2008) menggunakan media konkret dalam pembelajaran akan membantu siswa untuk mempertahankan ingatan lebih lama mengenai materi yang sedang dipelajari. Selain itu, media konkret juga terbukti membantu dalam meningkatkan visual thinking siswa dalam pembelajaran geometri, dimana visual thinking mempermudah dalam pemahaman atas masalah (Kania, 2017).

Ditinjau berdasarkan empat langkah penyelesaian masalah oleh Polya (1973), yakni memahami masalah, membuat strategi pemecahan masalah, melakukan strategi penyelesaian masalah, dan meninjau kembali hasil penyelesaian, kemampuan pemecahan masalah siswa meningkat pada semua langkah penyelesaian masalah. Baik indikator 1, indikator 2, indikator 3, dan indikator 4, dilihat dari perbandingan hasil jawaban pretest dan posttest siswa, menunjukkan adanya peningkatan pada semua langkah penyelesaian masalah oleh Polya. Perbandingan hasil pretest dan posttest siswa untuk Indikator 1 dapat dilihat pada Gambar 1. Perbandingan hasil pretest dan posttest siswa untuk Indikator 2 dapat dilihat pada Gambar 2. Perbandingan hasil pretest dan posttest siswa untuk Indikator 3 dapat dilihat pada Gambar 3. Perbandingan hasil pretest dan posttest siswa untuk Indikator 4 dapat dilihat pada Gambar 4. 
Jawaban:

Diketahui $=$

$\overline{E D} \| \overline{B A}$

Ditany $a=$

Berapakah besar $\angle D C B$ ?

Jawab:

$155^{\circ}-102^{\circ}=53^{\circ}$.

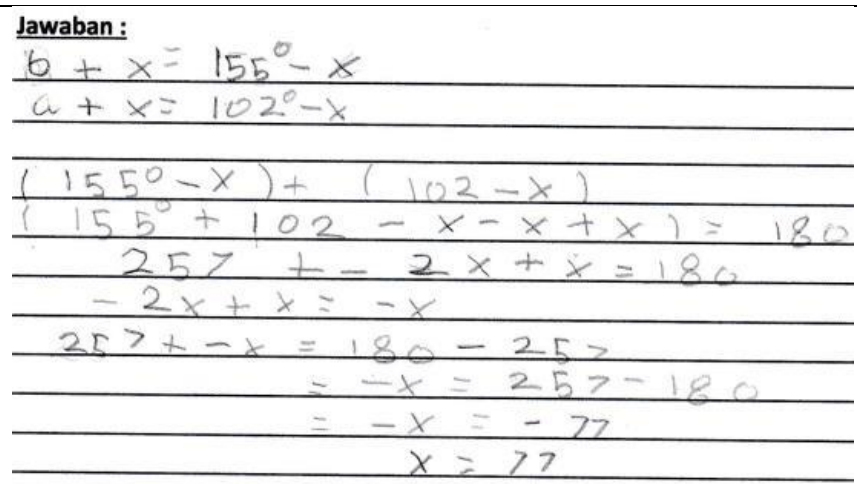

Gambar 1. (Atas) Hasil pre-test indikator 1/soal no.7; (Bawah) Hasil Post-test indikator 1/soal no 7

Peningkatan kemampuan siswa dalam memahami masalah yang terlihat pada ke-empat gambar yang tersaji, menunjukkan bahwa mulamula siswa tidak mampu untuk memahami masalah dengan baik. Siswa cenderung menerka setiap masalah yang diajukan dengan memperhatikan gambar dan informasi yang disajikan pada soal. Contoh peningkatan kemampuan memahami masalah siswa dapat dilihat pada Gambar 1 dan Gambar 2.

Pada Gambar 1 (atas), jawaban pretest terlihat seolah-olah siswa memahami masalah yang ditanyakan, namun kenyataan yang didapat setelah dilakukan wawancara, siswa hanya melakukan penerkaan untuk menjawab masalah yang disajikan. Siswa melihat gambar pada soal, terdapat "tanda tanya" pada salah satu sudut yang tersaji, maka siswa mengambil kesimpulan bahwa tanda tanya itu harus di selesaikan. Siswa beranggapan untuk menyelesaikan "tanda tanya" tersebut, dibutuhkan 
sebuah angka. Angka dipilih menjadi solusi dikarenakan pada sudut-sudut lainnya terdapat angka (besar sudut).

Siswa mengetahui bahwa ada angka yang harus dicari untuk menyelesaikan masalah, namun siswa tidak memahami bahwa angka tersebut merupakan besaran sudut. Setelah mendapatkan pembelajaran dengan penemuan terbimbing, siswa sudah memahami masalah pada indikator 1 dengan baik. Siswa dengan sadar menuliskan bahwa yang akan diselesaikan adalah besaran dari sudut yang ditanyakan.

Jawaban pada hasil post-test (Gambar 1, bawah) menunjukkan bahwa ada perubahan pola pemahaman masalah oleh siswa. Terlihat bahwa siswa mamahami dengan baik masalah yang disajikan. Hasil lembar jawaban menyajikan hasil akhir berupa besaran sudut $\mathrm{X}$. Bermakna bahwa siswa dengan tepat memahami sudut yang menjadi pertanyaan dalam masalah.

Gambar 2 (atas), menunjukkan adanya kesalahan dalam menentukan besaran sudut yang akan dicari. Pada soal, masalah akan terselesaikan bila besaran penyiku sudut B ditemukan. Namun, siswa beranggapan bahwa besaran sudut A yang harus dicari sebagai solusi utama dari masalah. Solusi yang dituliskan oleh siswa juga menunjukkan dengan jelas bahwa siswa sama sekali tidak memahami masalah. Siswa beranggapan untuk mencari besaran sudut $\mathrm{A}$, dapat diperoleh dari proses pengurangan besaran sudut A dan sudut B.

Selama wawancara, siswa tidak mampu menjelaskan mengapa sudut A dicari besarannya sedangkan pada solusi telah diketahui besaran sudut A, sehingga dapat dikurangkan dengan besaran sudut B untuk mendapatkan sudut A tersebut. Hal ini menunjukkan bahwa, siswa tidak memahami masalah yang diajukan secara tepat. Gambar 2 (bawah), menunjukkan perubahan dalam pemahaman siswa atas masalah yang diajukan. Pada Gambar 2 (bahwa) siswa telah menyadari bahwa besaran sudut yang harus diselesaikan adalah besaran penyiku sudut B. 


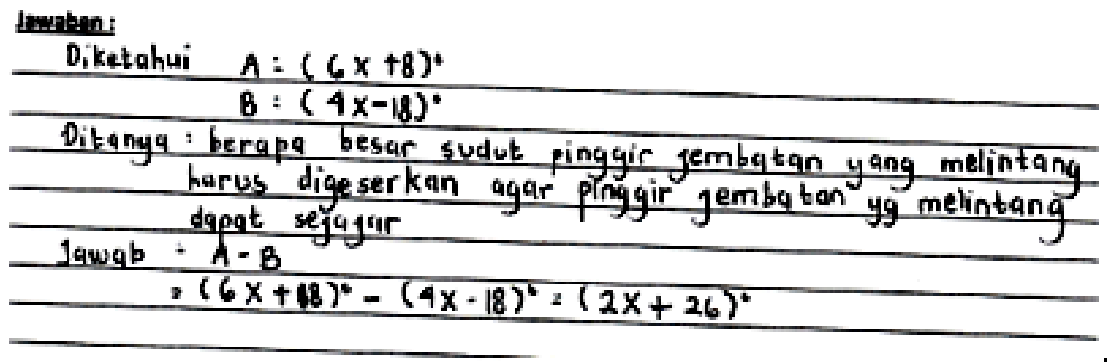

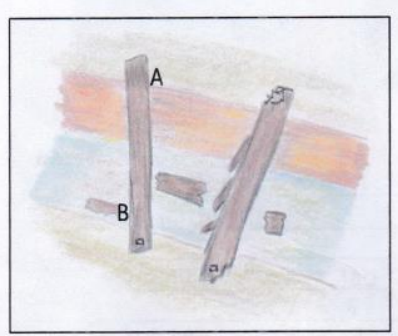

Gambar 2a. Jembatan yang rusak Jawaban: Diketahui $\angle A=(6 x+8)$

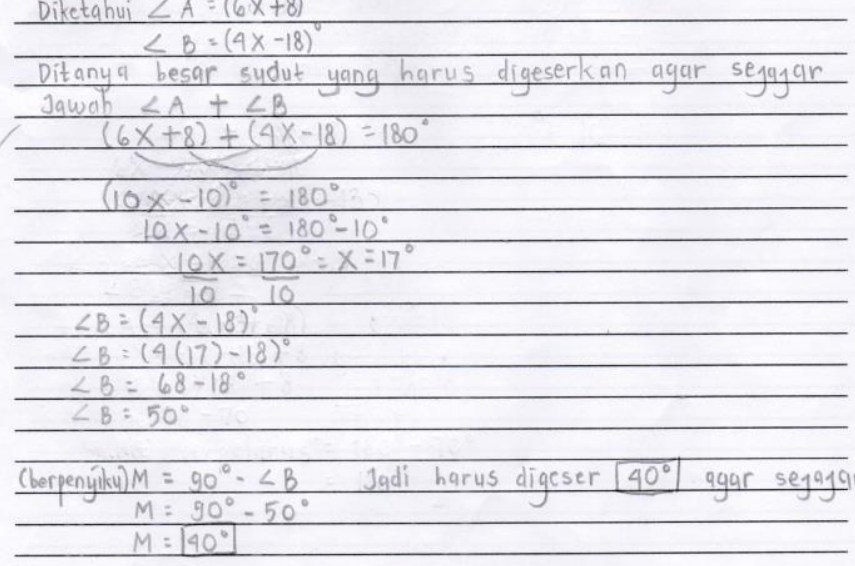

Gambar 2. (Atas) Hasil pre-test indikator 2/soal no.5; (Bawah) Hasil Post-test indikator 2/soal no.5

Peningkatan kemampuan siswa dalam memahami masalah dapat terjadi dikarenakan proses pembelajaran pada model penemuan terbimbing pada tahap stimulation dan problem statement. Tahap stimulation dan problem statement menggiring siswa untuk membangun 
pemahaman awal mengenai materi garis dan sudut. Siswa diajak untuk berfikir dan membayangkan masalah-masalah pada kehidupan sehari-hari yang berkaitan dengan materi garis dan sudut. Pada tahapan ini, siswa dilatih untuk secara mandiri berfikir mengenai solusi yang mungkin digunakan dalam menyelesaikan masalah yang disajikan. Tahapan ini merupakan tahapan awal dalam megembangkan kemampuan pemecahan masalah khususnya kemampuan pemahaman (Syah, 2006; Markaban, 2006; Gulo, 2008; Arsefa, 2015).

Kemampuan siswa membuat dan melakukan strategi penyelesaian masalah, meningkat setelah dilakukan pembelajaran melalui model penemuan terbimbing. Gambaran peningkatan kemampuan membuat dan melakukan strategi penyelesaian masalah dapat dilihat pada Gambar 3 dan Gambar 4. Gambar 3 (Atas) menunjukkan mula-mula siswa tidak mampu untuk menemukan strategi penyelesaian yang dapat digunakan untuk menyelesaikan masalah. Pada lembar jawaban, terlihat bahwa siswa hanya menyajikan besaran sudut $d$ tanpa proses penyelesaian terlebih dahulu.

Selama wawancara, siswa tidak mampu untuk mengungkapkan alasan dari jawaban yang telah dia sajikan, dan tidak mampu menjelaskan proses menuju hasil yang telah ditulis. Siswa juga tidak mampu untuk menjelaskan, mengapa pada point "jawab" yang siswa tulis tidak bersesuaian dengan point "ditanya". Ada delapan sudut yang menjadi masalah pada point "ditanya", sedangkan pada point "jawab" hanya ada satu besaran sudut saja. Hal ini, selain mengungkapkan bahwa siswa tidak mampu menyusun strategi penyelesaian, dikarena siswa tidak memahami titik pokok dari masalah yang diajukan. Tidak ada penyelesaian masalah, tanpa memahami masalah terlebih dahulu.

Berbeda dengan hasil post-test, yang terlihat pada Gambar 3 (bawah), lembar jawaban menunjukkan bahwa siswa memiliki strategi penyelesaian yang tepat serta siswa mampu menerapan strategi tersebut dengan benar. Bahkan ada penjelesan mengenai alasan dibalik setiap besaran sudut yang disajikan (karena "berpelurus" dank arena "bertolak belakang"). Tergambar jelas bahwa siswa dengan sadar mengerti proses apa yang harus ditempuh dan teori apa yang dapat digunakan untuk 
menyelesaikan masalah yang tersaji. Meskipun, siswa melewatkan syarat lain yang harus diperhatikan pada masalah, yakni perbandingan besaran sudut $x$ dan sudut $d$ adalah 1:2.

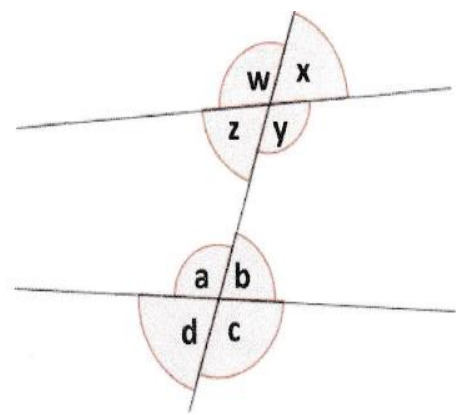

Bila diketahui perbandingan $\angle \mathrm{x}$ dan $\angle \mathrm{d}$ adalah $1: 2$, dan besar sudut $\mathrm{x}$ lebih dari $0^{\circ}$ dan kurang dari $70^{\circ}$, berapakah besar sudut a, b, c, d, w, x, y, dan z?

Setelah mendapatkan jawaban, periksalah kebenaran dari jawabanmu, dan tuliskan bagaimana kamu memastikan bahwa jawabanmu sudah benar.

Jawaban:

Diketahui: perbandingan $\angle x \& \angle d=1: 2$ besar sudut $x$ lebih dari $0^{\circ} \&$ kurang dari $70^{\circ}$

Ditanya: bescir sudut $a, b, c, d, w, x, y \& z$ Jawab: $35^{\circ}(<d)$

Jawaban:

\begin{tabular}{l} 
Diketahui besar sudut $x\left(0^{\circ} \angle x<70^{\circ}\right)$ \\
\hline Ditanya besar sudat $a, b, c, d, w, x, y$ dan $z$ \\
\hline Jawab \\
\hline Besar $x=65^{\circ}$ \\
Besar $W=180^{\circ}-65^{\circ}=115^{\circ}$ karena berpelurus dengan $x$ \\
\hline Besar $A=115^{\circ}$ karena berpelurus dengan $\angle b$ \\
\hline Besar $B=65^{\circ}$ karena berpelurus dengan $\angle A$ \\
\hline Besar $C=115^{\circ}$ karena bertolak belakang dengan $\angle A$ \\
\hline Besar $D=65^{\circ}$ karena bertolak belakang dengan $\angle b$ \\
Besar $y=115^{\circ}$ karena berpelurus dengan $\angle z$ \\
\hline Besar $z=65^{\circ}$ karena bertolak belakang dengan $\angle X$
\end{tabular}

Gambar 3. (Atas) Hasil pre-test indikator 3/soal no.4; (Bawah) Hasil Post-test indikator 3/soal no.4 
Dalam sesi wawancara, ketika siswa diminta untuk membaca dan memahami kembali masalah serta hasil yang telah siswa sajikan, siswa dengan cepat menemukan kesalahan yang telah dia perbuat. Siswa menyadari bahwa dia tidak menggunakan syarat kedua tentang perbandingan sudut $x$ dan sudut $d$. Siswa dengan cepat memperbaiki kesalahan yang telah dibuat. Siswa mengaku, bahwa dia tidak teliti untuk membaca setiap masalah dan informasi yang tersaji pada soal.

6. Pelangi terbentuk ketika cahaya matahari dipantulkan pada berbagai sudut yang berbeda oleh air hujan. Hal tersebut mengakibatkan timbulnya berbagai macam warna yang terlihat di langit seperti yang terlihat pada gambar. Warna biru terbentuk ketika cahaya matahari dipantulkan pada $\angle 2$. Bila besar $\angle 3$ lebih besar dari $120^{\circ}$ dan lebih kecil dari $180^{\circ}$, berapakah besar $\angle 2$ dengan ketentuan besar semua sudut adalah bilangan bulat?

Setelah mendapatkan jawaban, periksalah kebenaran dari jawabanmu, dan tuliskan bagaimana kamu memastikan bahwa jawabanmu sudah benar.

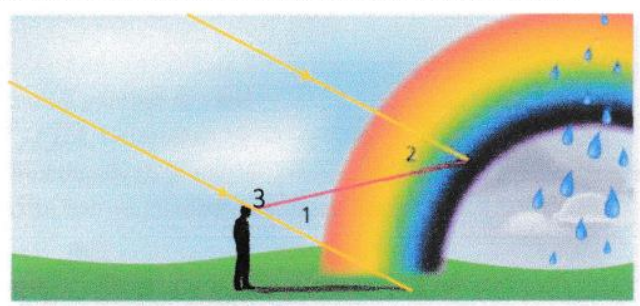

Jawaban:

Diketahul = warna biru terbentuk ketika cahaya matahari dipantulkan Pada gambar $\angle 2$

= Bila besar $\angle 3$ lebih besar dari $120^{\circ}$ dan lebih Kecil dari $180^{\circ}$ Ditanya = Berapa besar $\angle 2$ dengan Ketentuan besar semua sudut adalah bilangan bulat?

Di Jawab $=145^{\circ}$

Jawaban:

Diketahul

Besar $\angle 3$ lebih besar dari $120^{\circ}$ dan lebih kecil dari $180^{\circ}$

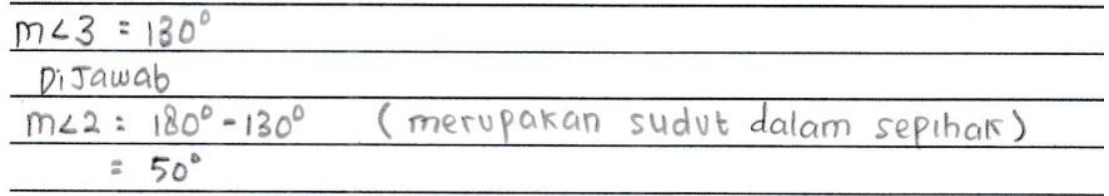

Gambar 4. (Atas) Hasil pre-test indikator 4/soal no.6; (Bawah) Hasil Post-test indikator 4/soal no.6 
Tidak jauh berbeda dengan peningkatan kemampuan siswa membuat dan melakukan strategi penyelesaian masalah yang tersaji pada Gambar 3, Gambar 4 juga menyajikan peningkatan yang serupa. Terlihat antara sebelum dan sesudah pembelajaran penemuan terbimbing, mulamula siswa hanya menerka tanpa memiliki proses penyelesaian atas hasil jawaban yang disajikan. Namun berbeda setelah pembelajaran penemuan terbimbing berlangsung, siswa mampu menyajikan proses dengan benar, memberikan informasi yang tepat mengenai teori yang digunakan, serta ketepatan perhitungan yang akurat.

Peningkatan kemampuan siswa membuat dan melakukan strategi/rencana penyelesaian masalah, merupakan dampak positif penerapan pembelajaran penemuan terbimbing, tahap data collection dan data processing. Kegiatan dalam kedua tahapan ini merupakan rangkaian kegiatan penemuan. Siswa secara mandiri dalam menemukan dan membangun pemahaman atas teori-teori yang dibutuhkan untuk menyelesaikan masalah. Siswa secara aktif menemukan teori baru, dengan menggunakan atau tanpa menggunakan teori yang telah ia kuasai sebelumnya (Markaban, 2006; Syah, 2006).

Gambaran mengenai peningkatan kemampuan siswa dalam meninjau kembali hasil penyelesaian dapat terlihat selama proses wawancara. Secara tertulis, tidak tergambarkan dengan jelas, apakah siswa melakukan peninjauan kembali terhadap hasil yang telah disajikan atau tidak. Namun, secara lisan, berdasarkan hasil wawancara, 80\% siswa melakukan peninjauan kembali terhadap penyelesaian masalah yang mereka bangun, sebelum mengumpul lembar jawabannya. Namun, meski telah melakukan peninjaun kembali terhadap penyelesaian masalah yang disajikan, dikarenakan ketidaktelitiannya, sebagian siswa tetap melakukan kesalahan pada penyelesaian masalah terutama pada proses perhitungan.

Ada dua tipe cara peninjauan hasil penyelesaian masalah oleh siswa. Tipe pertama, siswa hanya meninjau kebenaran proses perhitungan pada hasil penyelesaian, tanpa memperhatikan kebenaran pada teori yang telah digunakan. Tipe kedua, siswa meninjau ketepatan dan keakuratan hasil penyelesaian baik pada proses perhitungan maupun teori yang digunakan. 
Kemampuan siswa dalam meninjau kembali hasil penyelesaian meningkat seiring dengan pembiasaan meninjau kembali hasil penyelesaian pada setiap proses pembelajaran penemuan terbimbing. Setelah siswa melakukan serangkaian proses penemuan hingga mendapatkan hasil selama proses pembelajaran, siswa selalu dituntut untuk mengungkapkan secara tertulis cara siswa memastikan bahwa penemuannya adalah benar. Meskipun pada hasil posttest terkesan bahwa kegiatan pembiasaan "meninjau kembali" tidaklah berhasil, namun nyatanya siswa melakukan peninjauan kembali hasil penyelesaian masalah yang ia sajikan meskipun tidak dituliskan. Sebagian siswa menganggap, cukup kegiatannya saja yang dilakukan tanpa harus dituliskan, dikarenakan waktu yang diberikan untuk mengerjakan posttest sangat terbatas.

\section{SIMPULAN}

Pembelajaran penemuan terbimbing mampu meningkatkan kemampuan pemecahan masalah siswa. Meskipun bila dilihat dari nilai total, peningkatan kemampuan pemecahan masalah siswa tergolong dalam kategori rendah, namun dilihat dari masing-masing indikator kemampuan pemecahan masalah, peningkatan kemampuan pemecahan masalah terjadi pada dua dari empat indikator yang tergolong dalam kategori sedang. Indikator 2 dan indikator 4 yang mengalami peningkatan dalam kategori sedang, menunjukkan bahwa siswa mudah untuk memahami dan menyelesaikan masalah yang berkaitan dengan kejadian di kehidupan sehari-hari. Siswa mampu menyelesaikan masalah baik tertutup dan terbuka dengan konteks di luar matematika yakni konteks yang bekenaan dengan kehidupan sehari-hari.

Ditinjau dari langkah penyelesaian oleh Polya (1973), siswa mengalami peningkatan pada keempat langkah tersebut, yakni memahami masalah, membuat strategi pemecahan masalah, melakukan strategi penyelesaian masalah, dan meninjau kembali hasil penyelesaian. 


\section{DAFTAR PUSTAKA}

Aini, I. N., \& Hidayati, N. (2017). Tahap perkembangan kognitif matematika siswa SMP kelas VII berdasarkan teori Piaget ditinjau dari perbedaan jenis kelamin. JPPM (Jurnal Penelitian dan Pembelajaran Matematika), 10(2).Akinbobola, A. O \& Afolabi, F. (2010). Contructivist Practice Through Guided Discovery Approach: The Effect on Students' Cognitive Achievement in Nigerian Senior Secondary School Physics. Eurasian Journal Physics and Chemistry Education, 2(1),pp. 16-25. Retrieved from http://jurnal.untirta.ac.id/index.php/JPPM/article/view/2027

Arsefa, D. (2015). Peningkatan kemampuan berfikir kreatif matematis dan self-confidence siswa SMP melalui resources-based learning (RBL) dengan pendekatan saintifik. (Tesis). Sekolah Pascasarjana, Universitas Pendidikan Indonesia, Bandung

Devlin, K. (2007). Helping children learn mathematics. Publish by the National Academy Press. Retrieved from http://www.maa.org/devlin/devlin0907.html

Herawati, O D P., dkk. (2010). Pengaruh Pembelajaran Problem Posing terhadap Kemampuan Pemahaman Konsep Matematika Siswa Kelas XI IPA SMA Negeri 6 Palembang. Dalam Jurnal Pendidikan Matematika Volume 4. No.1. Retrieved from https://ejournal.unsri.ac.id

Hevriansyah, P., \& Megawanti, P. (2017). Pengaruh kemampuan awal terhadap hasil belajar matematika.JKPM (Jurnal Kajian Pendidikan Matematika), 2(1), 37-44. Retrieved from https://journal.lppmunindra.ac.id/index.php/jkpm/article/view/1893

Husna, dkk. (2013). Peningkatan Kemampuan Pemecahan Masalah dan Komunikasi Matematis Siswa Sekolah Menengah Pertama Melalui Model Pembelajaran Kooperatif Tipe Think-Pair-Share (TPS). Jurnal Peluang Vol 1, No. 2, April 2013, ISSN: 2302-5158. Retrieved from http://e-repository.unsyiah.ac.id/

Gulo, W. (2008). Strategi Belajar Mengajar. Jakarta: Grasindo 
Jacob, C. (2003). Konstruktivisme \& Metakognitif. Bandung: Universitas Pendidikan Indonesia Fakultas Pendidikan Matematika dan IPA

Kania, N. (2017). Efektivitas Alat Peraga Konkret terhadap Peningkatan Visual Thinking Siswa. Jurnal Theorems, 1(2), 301715. Khan, S. (2013). The One World School House. Jakarta: Noura Books. Retrieved from https://www.neliti.com/publications/ 301715/efektivitas-alat-peraga-konkret-terhadap-peningkatanvisual-thinking-siswa

Kilpatrick, J., \& Swafford, J. (2002). Helping children learn mathematics. National Academy Press

Lestari, W. (2017). Pengaruh Kemampuan Awal Matematika dan Motivasi Belajar Terhadap Hasil Belajar Matematika. Jurnal Analisa, 3(1), 76-84. Markaban. (2006). Model Pembelajaran matematika dengan pendekatan penemuan terbimbing. Yogayakarta: PPPG Matematika. Retrieved from https://journal.uinsgd.ac.id/index.php/analisa/article/view/1499

Mulyadi, M., Riyadi, R., \& Subanti, S. (2015). Analisis Kesalahan Dalam Menyelesaikan Soal Cerita Pada Materi Luas Permukaan Bangun Ruang Berdasarkan Newman's Error Analysis (Nea) Ditinjau Dari Kemampuan Spasial. Jurnal Pembelajaran Matematika, 3(4). Retrieved from http://www.jurnal.fkip.uns.ac.id/

NCTM. (2000). Principle and Standars for school mathematics. National Council of Teachers of Mathematics

Nugroho, I. D., \& Widodo, S.A. (2018). Pembelajaran Matematika dengan Metode Penemuan Terbimbing untuk Meningkatkan Kemampuan Representasi dan Pemecahan Masalah Matematis Siswa SMK. In Prosdiding Seminar Nasional Pendidikan Matematika Etnomatnesia. $\quad$ Retrieved from http://www.jurnal.ustjogja.ac.id/

Prabawanto, S. (2013). Peningkatan Kemampuan Pemecahan Masalah, Komunikasi, dan Self-Efficacy Matematis Mahasiswa melalui Pembelajaran dengan Pendekatan Metacognitive Scaffolding. S3 Tesis, Universitas Pendidikan Indonesia 
Polya, G. (1973). How to Solve It A New Aspevt of Mathematical Method. New Jersey: Princeton University Press

Rahmawati, A. (2014). Meningkatkan Kemampuan Pemahaman Matematika Siswa SMP Melalui Metode Penemuan Terbimbing. Prosiding Seminar Nasional Pendidikan Matematika Program Pascasarjana STKIP Siliwangi Bandung. Vol. 1. Retrieved from https://ikipsiliwangi.ac.id/semnasmat/

Rosdianwinata, E. (2015). Penerapan metode discovery untuk meningkatkan kemampuan pemecahan masalah matematika siswa. Jurnal Kajian Pendidikan dan Pengajaran, 1(1), pp. 1-7. Retrieved from http://jm.ejournal.id/index.php/mendidik/article/view/1

Ruseffendi, E. T. (2006). Pengantar Kepada Membantu Guru Mengembangkan Kompetensinya dalam Pengajaran Matematika untuk Meningkatkan CBSA. Bandung: Tarsito

Santrock, J. W. (2012) Life Span Development: Perkembangan Masa Hidup Edisi Ketigabelas. Jakarta :Erlangga

Schunk, D. H. (2012). Learning Theories: an Educational Perspective. Yogyakarta: Pustaka Pelajar

Setyawan, I. K. A. (2012). Analisis Korelasi Kompleksitas Materi, Daya Dukung, dan Intake Siswa Terhadap Prestasi Belajar Biologi pada Sekolah Menengah Pertama (SMP) Negeri di Kecamatan Kuta Kabupaten Badung. Jurnal Penelitian dan Evaluasi Pendidikan Indonesia, 2(1). Schunk, D. H. (2012). Learning Theories: an Educational Perspective. Yogyakarta: Pustaka Pelajar. Retrieved from http://119.252.161.254/e-journal/index.php/jurnal_ep/article/ view/30

Sternberg, R. J \& Ben-Zeev, T. (1996). The nature of mathematical thinking. Mahwah, $\mathrm{Nj}$ : Lawrence Erlbaum Associates, Inc

Sudijono, A. (2011). Evaluasi Pendidikan. Jakarta: Raja Grafindo Persada

Sugiyono. (2014). Statistika untuk Penelitian. Bandung:Alfabeta

Suhendar (2008). Pengaruh Penambahan Waktu Belajar Agama Islam Terhadap Prestasi Belajar Siswa Pada Mata Pelajaran PAI. Jurnal 
Pendidikan Universitas Garut. Vol. 02, No 01, 2008, 26-36. Retrieved from https://eprints.uny.ac.id/7407/

Sumarmo, U. (2012). Proses berpikir matematik: apa dan mengapa dikembangkan. Bahan belajar matakuliah proses berpikir matematik program S2 pendidikan matematika STKIP Siliwangi. Retrieved from https://www.academia.edu/10346582/

Suryadi, D \& Herman, T. (2004). Eksplorasi matematika: pembelajaran pemecahan masalah. Jakarta: Karya Duta Wahana

Suryadi,D (2012). Membangun Budaya Baru dalam Berpikir Matematika. Bandung: Rizqi Press

Syah, M. (2006). Islamic English: A Competency-Based Reading Comprehension. Bandung: PT Remaja Rosdakarya

Uhti. (2011). Pembelajaran Kooperatif dengan Pendekatan Open Ended untuk Meningkatkan Kemampuan Pemecahan Masalah Matematis Siswa Sekolah Menengah. Prosiding Seminar Nasional Matematika dan Pendidikan Matematika Pada Tanggal 3 Desember 2011 Di jurusan Pendidikan Matematika FMIPA UNY. Retrieved from https://eprints.uny.ac.id

Yee, F. P (2002a). The role of problem to enhance pedagogical practice in Siangpore mathematics classroom. The mathematics educator. Vol.6, No.2, 15-31, 2002

Yee, F. P (2002b). Using short open-ended mathematics question to promote thinking and understanding. Retrieved from : http://math. unipa. it/ grim/SiFoong. PDF 